\title{
KUNCI TEKNOLOGI 5G
}

\author{
Ulil Surtia Zulpratita \\ Prodi Teknik Informatika \\ Universitas Widyatama \\ Jl Cikutra 204A Bandung \\ ulil.zulpratita@widyatama.ac.id
}

\begin{abstract}
Abstrak
Proses kelengkapan standarisasi teknologi 5G diharapkan akan selesai sebelum Oktober 2020. Resminya standarisasi ini akan menjadi hal penting untuk komersialisasi jaringan 5G. Teknologi 5G diprediksi akan membutuhkan transformasi akan kebutuhan frekuensi carrier yang sangat tinggi dengan bandwidth yang sangat lebar, densitas ekstrim untuk berbagai divais dan base station, serta sejumlah besar antena. 5G tidak akan menjadi antarmuka udara tunggal sebagaimana pada model generasi sebelumnya. 5G diprediksi akan sangat integratif: jalinan koneksi antarmuka udara dan spektrum 5G bersama-sama dengan teknologi nirkabel yang sudah ada (misalnya: LTE dan WiFi) akan memberikan layanan dengan pesat data tinggi dan cakupan luas, serta menjamin terwujudnya pengalaman pengguna tanpa hambatan. Untuk mendukung hal tersebut, di bagian core network harus berevolusi untuk mencapai tingkat belum pernah terjadi sebelumnya dalam hal fleksibilitas dan kecerdasan, regulasi spektrum perlu dikaji kembali dan direvisi, masalah energi dan efisiensi biaya juga akan menjadi pertimbangan yang penting. Berdasarkan studi literatur yang telah dilakukan, artikel ini akan mengidentifikasi dan merumuskan empat kunci penting implementasi teknologi 5G.
\end{abstract}

Kata kunci : implementasi 5G, massive MIMO, jaringan hybrid, mmWave, unified air interface

\section{Abstract}

$5 G$ standardization process is expected to be finished before October 2020. This standardization is essential for making $5 G$ network's commercial deployment. The $5 G$ technology is forecasted to demand a transformation in the need for very high carrier frequencies with very extensive bandwidth, extreme density for devices and base stations, as well as large numbers of antennas. $5 G$ will not be a distinct air interface based on Radio Access Technology as in former generation models. $5 G$ is predicted to be immensely collaborative: the linkage of air interface and $5 G$ spectrum together with existing wireless technologies (for example: LTE and WiFi) will provide services with universal high-rates coverage and ensure seamless user experience. To support this, the core network must also evolve to achieve an extraordinary level of adjustability and intelligence, spectral standardization needs to be reviewed and revised, energy issues and cost efficiency will also be an important attention. Based on studies that had been done, this article will discuss and identify the four significant keys to the implementation of $5 G$ technology.

Keywords : $5 G$ implementation, massive MIMO, hybrid networking, mmWave, unified air interface

\section{Pendahuluan}

Teknologi 5G adalah generasi baru dari sistem radio dan arsitektur jaringan yang akan menghadirkan konektivitas broadband, ultra-robust, low latency yang ekstrim, dan jaringan masif untuk manusia dan Internet of Things (Nokia, 2016; 5G PPP, 2016; Arjmandi, 2016; Sexton, 2017). Lain halnya dengan sistem nirkabel single-purpose, 5G dipersiapkan untuk menyediakan segudang layanan untuk berbagai perangkat jaringan heterogen yang terus bertambah (atau disebut mesin) yang mampu berkomunikasi satu sama lain. Dengan kata lain, Internet of Things (IoT) dan komunikasi Machine to Machine (M2M) berskala besar akan memanfaatkan sistem nirkabel 5G. Hal ini tentunya akan menempatkan beragam persyaratan pada jaringan dalam hal konsumsi energi, biaya perangkat, latensi, kehandalan, dan sebagainya. 
Big data adalah area lain yang dapat menciptakan tantangan sekaligus peluang sistem nirkabel 5G. Aplikasi IoT dan M2M yang disebutkan di atas akan menghasilkan sejumlah besar volume data, sehingga menimbulkan tantangan teknis utama pada jaringan akses radio. Software Defined Networking (SDN) dan Network Function Virtualization (NFV) muncul dari kebutuhan menjalankan aplikasi big data, keduanya memiliki sinergi yang erat dengan komputasi awan (cloud computing) (Nokia, 2016; 5G PPP, 2016). Teknologi ini pada titik tertentu akan bergabung membentuk platform $5 \mathrm{G}$ yang sangat kuat untuk layanan big data.

5G akan jauh lebih dari sekedar teknologi radio baru. 5G akan menggabungkan Radio Access Technology (RAT) yangada, baik di band berlisensi maupun yang tidak berlisensi, dan akan menambahkan RAT baru yang sudah dioptimasi untuk spesifikasi band, deployment, skenario, dan use case tertentu. 5G juga secara radikal akan menerapkan arsitektur jaringan baru berdasarkan teknologi SDN dan NFV. Kemampuan program akan menjad hal krusial yang dibutuhkan operator telekomunikasi untuk mencapai hiper-fleksibilitas guna mendukung tuntutan baru komunikasi dari beragam pengguna, mesin, perusahaan dari berbagai industri, dan organisasi lainnya. Jaringan $5 \mathrm{G}$ harus bersifat programmable, software driven dan dapat dikelola secara holistik untuk memungkinkan beragam layanan dan jangkauan yang beragam (Ohlen, 2015; Qualcomm, 2016). Berdasarkan tinjauan pustaka yang sudah dilakukan, tulisan dalam artikel ini akan merangkum empat hal penting yang diperlukan agar teknologi $5 \mathrm{G}$ bisa memenuhi beragam tuntutan layanan tersebut.

\section{SPESIFIKaSi Layanan TeKNOLOGI 5G (IMT-2020)}

Istilah IMT-2020 diciptakan pada tahun 2012 oleh International Telecommunication Union Radiocommunication Sector (ITU-R) yang berarti International Mobile Telecommunication (IMT) dengan target yang ditetapkan pada tahun 2020. IMT2020 inilah yang merupakan istilah resmi untuk teknologi 5G.

5G didesain untuk melayani tiga karakteristik ekstrim layanan seluler, yaitu enhanced Mobile Broadband (eMBB), ultra-Reliable and Low Latency
Communications ( $u R L L C)$, dan massive Machine Type Communications (mMTC) [7]. eMBB bertujuan untuk memenuhi permintaan individu end-user akan gaya hidup digital yang semakin meningkat, dan berfokus pada layanan yang memiliki persyaratan bandwidth tinggi, seperti video High Definition (HD), Virtual Reality (VR), dan Augmented Reality (AR). uRLLC bertujuan untuk memenuhi ekspektasi dan tuntutan industri digital serta berfokus pada layanan sensitif latensi. mMTC bertujuan untuk memenuhi tuntutan lingkungan digital yang dikembangkan lebih lanjut dan berfokus pada layanan yang mencakup persyaratan kepadatan koneksi yang tinggi, misalnya pada penerapan sistem kota cerdas (smart city) dan pertanian cerdas (smart agriculture). Tiga karakteristik utama layanan teknologi $5 \mathrm{G}$ ditunjukkan pada Gambar 1 dan Tabel 1.

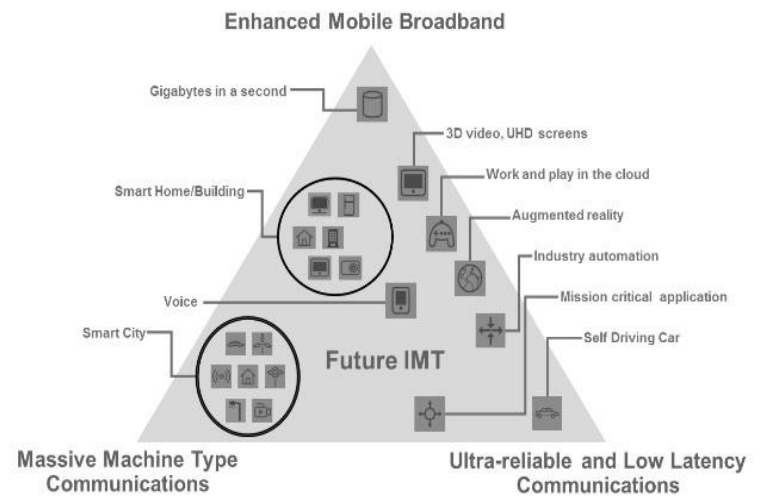

Gambar 1. Spesifikasi kategori layanan 5G (Dong, 2016)

Tabel 1. Tiga Karakteristik Layanan Teknologi 5G

\begin{tabular}{c|ll}
\hline $\begin{array}{c}\text { Layanan } \\
\text { Seluler 5G }\end{array}$ & \multicolumn{1}{c}{ Karakteristik Layanan } \\
\hline eMBB & - & $\begin{array}{l}\text { Puncak pesat data hingga 20 Gbps } \\
\text { Pesat data untuk user 100-1,000 } \\
\end{array}$ \\
& - & $\begin{array}{l}\text { Mbps } \\
\text { Efisiensi spektrum 5x lipat }\end{array}$ \\
\hline uRLLC & - & $\begin{array}{l}\text { Latency yang sangat rendah (1 ms) } \\
\text { Koneksi yang ultra-reliable untuk } \\
\text { mobilitas kecepatan tinggi (<=500 } \\
\text { km/j) }\end{array}$ \\
\hline mMTC & - & $\begin{array}{l}\text { Koneksi masif (1,000,000/km2) } \\
\text { Efisiensi energi jaringan 100x lipat }\end{array}$ \\
\hline
\end{tabular}




\section{KUNCI TEKNOLOGI 5G}

5G bertujuan untuk menyediakan akses informasi yang tak terbatas dan kemampuan untuk berbagi data dimanapun, kapanpun oleh siapapun dan apapun. Untuk memastikan bahwa jaringan akan dapat mengatasi lanskap layanan masa depan yang beragam, berbagai forum seperti NGMN (Next Generation Mobile Networks), ITU-R (International Telecommunication Union- Radiocommunication Sector), dan 5G PPP (5G Infrastructure Public Private Partnership) bekerja untuk mendefinisikan target kinerja sistem 5G (5G PPP, 2015).

Tabel 2. Tantangan dan Tuntutan Layanan Teknologi 5G

\begin{tabular}{|c|c|}
\hline Tantangan Teknologi 5G & $\begin{array}{c}\text { Tuntutan yang Harus } \\
\text { Dipenuhi }\end{array}$ \\
\hline $\begin{array}{l}\text { IoT dan jumlah koneksi - IoT } \\
\text { diprediksi akan membuat } \\
\text { peningkatan yang masif baik } \\
\text { dalam hal jumlah perangkat } \\
\text { maupun jumlah koneksi } \\
\text { jaringan nirkabel. Hal ini akan } \\
\text { menyebabkan munculnya } \\
\text { kebutuhan baru akan total } \\
\text { volume data dan pengelolaan } \\
\text { jumlah koneksi fisik. }\end{array}$ & $\begin{array}{l}\text { Mekanisme scheduling dan } \\
\text { access control yang baru, } \\
\text { serta pengurangan } \\
\text { pensinyalan control plane } \\
\text { untuk pengguna IoT. }\end{array}$ \\
\hline $\begin{array}{l}\text { Volume data - Pertumbuhan } \\
\text { volume data di jaringan seluler } \\
\text { adalah 25-50\% per tahun, dan } \\
\text { akan terus bertambah hingga } \\
2030 \text {. Hal ini bukan hanya } \\
\text { karena aplikasi yang } \\
\text { membutuhkan kecepatan data } \\
\text { yang lebih tinggi tetapi juga } \\
\text { karena peningkatan resolusi } \\
\text { layar dan perkembangan dalam } \\
\text { video 3D. }\end{array}$ & $\begin{array}{l}\text { Peningkatan kapasitas data } \\
\text { pada jaringan end-to-end, } \\
\text { tidak hanya pada jaringan } \\
\text { antarmuka udara tetapi } \\
\text { juga pada keseluruhan } \\
\text { jaringan acces/core. } \\
\text { Kemacetan data juga harus } \\
\text { dapat diatasi }\end{array}$ \\
\hline $\begin{array}{l}\text { Peningkatan kapasitas jaringan } \\
\text { tanpa meningkatkan biaya } \\
\text { operasi secara signifikan. }\end{array}$ & $\begin{array}{l}\text { Penggunaan } \\
\text { spektrum/sites/infrastruktur } \\
\text { yang sudah ada secara } \\
\text { lebih efisien, sehingga } \\
\text { kapasitas jaringan } \\
\text { meningkat tanpa adanya } \\
\text { tambahan biaya yang } \\
\text { signifikan serta tidak } \\
\text { menambah kompleksitas } \\
\text { arsitektur jaringan. }\end{array}$ \\
\hline $\begin{array}{l}\text { Penyebaran yang cepat dan } \\
\text { fleksibel. }\end{array}$ & $\begin{array}{l}\text { Arsitektur jaringan yang } \\
\text { fleksibel }\end{array}$ \\
\hline
\end{tabular}

Level kinerja maksimum jaringan tidak akan tercapai secara bersamaan untuk setiap aplikasi atau layanan. Sebagai gantinya, sistem 5G akan dibangun untuk memenuhi berbagai target kinerja, sehingga berbagai layanan dengan berbagai tuntutan yang berbeda dapat dibangun pada infrastruktur tunggal. Untuk membangun jaringan yang mampu menyediakan jenis konektivitas yang berbeda-beda tentunya memerlukan fleksibilitas dalam arsitektur system. Tabel 2 berisi tentang rumusan tantangan dan tuntutan layanan teknologi 5G yang harus dipenuhi.

Untuk memenuhi tantangan dan tuntutan layanan teknologi 5G pada Tabel 2, secara garis besar, kunci penting teknologi $5 \mathrm{G}$ terdiri atas empat hal, yaitu: Massive MIMO, Hybrid Networking, Lean Design dan Unified Air Interface, serta Versatile Network Architecture.

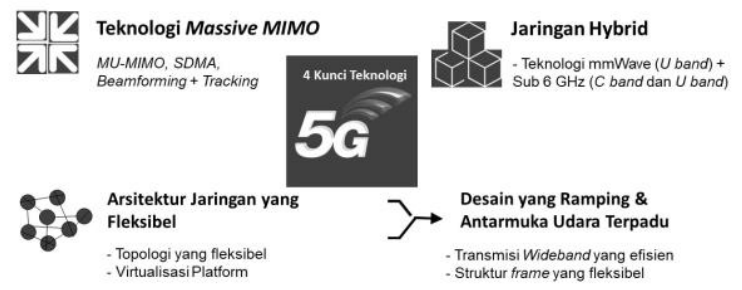

Gambar 2. Empat kunci penting teknologi 5G

\section{III.1 Teknologi Massive MIMO}

MIMO, Multiple-Input Multiple Output, adalah teknologi yang mengandalkan beberapa antena untuk mentransmisikan beberapa aliran data secara simultan dalam sistem komunikasi nirkabel. Massive MIMO, dapat digunakan untuk meningkatkan efisiensi spektral melalui transmisi multi-stream, atau membentuk narrow beam untuk meningkatkan jarak transmisi.

Normalnya, band sub-6 GHz memiliki bandwidth yang lebih kecil, namun transmisi multi-stream Massive MIMO dapat mencapai puncak pesat data hingga beberapa Gbps. Ukuran antena berbanding terbalik dengan frekuensi, sehingga ukuran fisik antena akan menentukan batas jumlah elemen antenna yang bisa digunakan. Keuntungan penggunaan teknologi Massive MIMO ditunjukkan pada Gambar 3. 

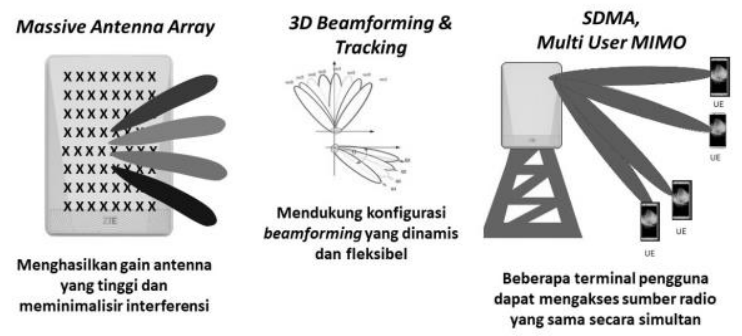

Gambar 3. Keuntungan penggunaan Massive MIMO

Band yang lebih tinggi memiliki bandwidth yang relatif besar, namun juga path loss yang lebih besar. Massive MIMO adalah cara efektif untuk mengkompensasi path loss pada band 3-40 GHz dengan menggunakan high beamforming gain untuk meningkatkan puncak pesat data (peak data rate) dengan cara transmisi multi stream. Untuk band frekuensi yang sangat tinggi (misalnya mmW, 30-100 $\mathrm{GHz}$ ), antena memusatkan energi yang ditransmisikan ke arah penerima untuk mengatasi path loss yang meningkat akibat propagasi radio (Nokia, 2016; 5G PPP, 2016). Banyak aliran MIMO paralel yang tidak diperlukan karena bandwidth yang besar tersedia di band frekuensi ini.

Teknologi Massive MIMO memungkinkan untuk digunakan berkomunikasi dengan beberapa terminal, atau yang disebut dengan teknologi Multi User MIMO (MU-MIMO). Penggunaan MU-MIMO dalam sistem seluler membawa peningkatan pada empat hal (Larsson, 2014):

a. Peningkatan pesat data, karena semakin banyak antena, semakin banyak aliran data independen yang dapat dikirim keluar dan semakin banyak terminal yang dapat dilayani bersamaan;

b. Peningkatan kehandalan (reliability), karena semakin banyak antena, semakin jelas jalur yang dapat disebarkan oleh sinyal radio;

c. Peningkatan efisiensi energi, karena base station dapat memfokuskan energi yang dipancarkan ke arah spasial dimana terminal berada;

d. Pengurangan interferensi karena base station dapat dengan sengaja menghindari transmisi ke arah penyebaran gangguan berada.

Semua peningkatan tersebut tidak dapat dicapai secara bersamaan, ada beberapa persyaratan yang harus dipenuhi pada kondisi propagasi, namun keempat poin di atas adalah keuntungan umum dari penggunaan MU-MIMO.

Tantangan lain yang harus dihadapi operator telekomunikasi dalam menyiapkan teknologi 5G adalah masalah jangkauan jaringan (network coverage). Sumber daya spektrum adalah sumber daya yang paling berharga dalam komunikasi nirkabel. Karena peningkatan lalu lintas stratosfer, pemanfaatan spektrum mengalami kemacetan teknis dengan teknologi nirkabel saat ini. Meningkatkan efisiensi spektrum menjadi masalah yang harus segera diselesaikan. Spektrum frekuensi lebih tinggi yang ditetapkan untuk jaringan $5 \mathrm{G}$ menyebabkan resiko path loss sinyal spektral yang lebih besar, sehingga secara teoritis akan menjadi tantangan besar bagi $5 \mathrm{G}$ untuk bisa memberikan cakupan sinyal (signal coverage) berkualitas tinggi. Di antara teknologi inti 5G yang ada, kunci untuk meningkatkan efisiensi spektrum dengan antarmuka udara adalah teknik SDMA (Space Division Multiple Access) (Larsson, 2014). SDMA dapat meningkatkan kapasitas sistem beberapa kali lipat tanpa frekuensi tambahan, serta sumber daya ruang dan waktu. Selain SDMA, teknik beam forming dan terminal dual-transmission channel precoding merupakan solusi penting bagi operator untuk mencapai cakupan jaringan (network coverage) yang setara atau lebih baik daripada 4G karena link gain yang dihasilkan.

\section{III.2 Jaringan Hybrid (Hybrid Networking)}

Teknologi millimeter wave (mmWave) dianggap sebagai kunci penting jaringan 5G untuk mencapai pesat data yang lebih tinggi dan daya transmisi rendah dengan memberi user beban SNR (signal- to-noise ratio) yang rendah. Jaringan mmWave yang beroperasi pada band frekuensi $\mathrm{E}$ dan $\mathrm{W}$ memiliki bandwidth $>=1 \mathrm{GHz}$ untuk menghasilkan pesat data yang lebih tinggi, sedangkan karakteristik propagasinya sangat berbeda dari jaringan Ultra High Frequency (UHF) konvensional yang beroperasi pada band frekuensi sub $6 \mathrm{GHz}$.

Implementasi mmWave pada base station berpotensi besar untuk meningkatkan penggunaan kembali radio resources secara spasial dan juga untuk meningkatkan efisiensi energi dan spektral jaringan. Meluasnya penggunaan ponsel pintar menghasilkan peningkatan trafik data yang signifikan sebagaimana dijelaskan di (Cisco, 2017). Lonjakan trafik dan kongesti yang terjadi dalam spektrum yang tersedia mendorong munculnya kebutuhan untuk beralih ke 
band frekuensi yang tidak terpakai. Penggunaan band mmWave mulai dari $10 \mathrm{GHz}$ sampai $300 \mathrm{GHz}$, merupakan solusi menarik untuk mengatasi masalah kongesti spektrum. Pada (Rappaport, 2014), ditunjukkan bahwa jaringan seluler mmWave bersifat noise limited, sedangkan jaringan seluler UHF konvensional bersifat interference limited.

Meskipun mmWave disepakati akan menentukan jaringan 5G, masih terdapat masalah yang harus dipecahkan berkaitan dengan tantangan mmWave. Berikut beberapa kelemahan mmWave (Heath, 2016; Rebato, 2017):

a. Penyerapan atmosfer. Sinyal mmWave diserap oleh atmosfer, sehingga akan membatasi jangkauan transmisi. Hujan, kabut dan kelembaban di udara membuat redaman sinyal sangat tinggi. Penyerapan oksigen pada $60 \mathrm{GHz}$ juga sangat tinggi.

b. Resonansi mekanis. Frekuensi resonansi mekanis dari molekul gas juga akan mengganggu sinyal gelombang milimeter. Untuk teknologi saat ini, puncak penyerapan terjadi pada $24 \mathrm{GHz}$ dan 60 GHz.

c. Scattering. Perambatan mmWave juga akan dipengaruhi oleh hujan karena tetesan air hujan berukuran kira-kira sama dengan panjang gelombang radio sehingga akan menyebabkan hamburan sinyal.

d. Non-Line of Sight (NLOS). Bila tidak ada jalur LoS antara pemancar dan penerima, sinyal transmisi masih memiliki cara alternatif untuk menjangkau penerima, baik melalui difraksi, refleksi atau pembengkokan (bending). Difraksi dalam mmWave jarang terjadi karena panjang gelombang yang pendek.

e. Suhu kecerahan (brightness temperature) Ketika mmWave diserap oleh uap air, oksigen dan hujan, molekul ini akan menyerap radiasi elektromagnetik frekuensi tinggi. Emisi energi ini, bila diterima oleh antena penerima, disebut suhu kecerahan (brightness temperature) dan menurunkan kinerja sistem.

Pada dasarnya band mmWave menghadirkan tiga fitur unik yang tidak terdapat pada band frekuensi yang lebih rendah. Pertama, karena bandwidth dan derajat kebebasan spasial yang besar, band mmWave bisa memiliki utilisasi yang sangat rendah jika keseluruhan bandwidth besar hanya dialokasikan secara eksklusif ke operator tunggal (Cuba, 2014; Rebato, 2016). Kedua, komunikasi mmWave biasanya ditandai dengan transmisi dengan beam yang sangat sempit. Ketiga, sinyal mmWave memiliki kekurangan dalam hal propagasi, seperti jangkauan yang relatif pendek dan sulitnya menyediakan koneksi handal, sehingga menimbulkan tantangan dalam hal menyediakan pengalaman pengguna yang konsisten.

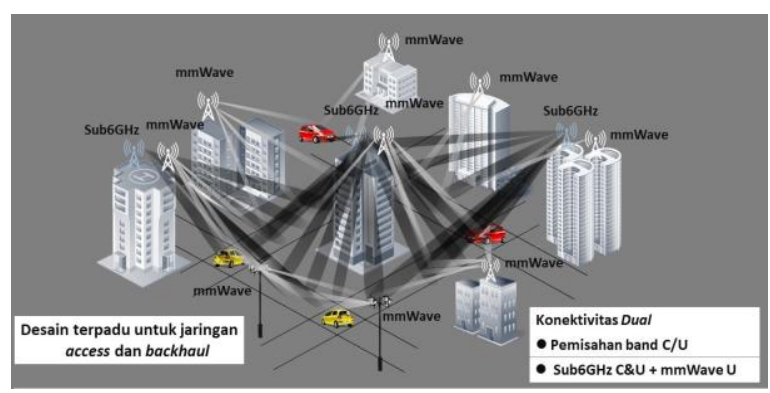

Gambar 4. Desain jaringan backhaul dan access pada 5G

Kesulitan yang terkait dengan mmWave membuat regulator dan operator seluler akan terus bergantung pada spektrum sub-6 GHz. Terlebih lagi karena dibutuhkan waktu untuk mengembangkan teknologi mmWave dan untuk menyelaraskannya dengan ketersediaan band spektrum baru. Dalam konteks distribusi heterogen (Ishii, 2012; Andrews, 2013; Ghosh, 2014; Elshaer, 2016), sebagian koneksi dilakukan dengan sebuah anchor di atas carrier sub-6 $\mathrm{GHz}$ dan sebagian lainnya dengan carrier mmWave. Ilustrasi desain jaringan backhaul dan access untuk 5G dengan menggabungkan mmWave yang menggunakan $U$ band serta sub-6 $\mathrm{GHz}$ yang menggunakan $C$ band dan $U$ band, ditunjukkan pada Gambar 4.

\section{III.3 Lean Design dan Unified Air Interface}

Standar teknologi 5G NR (New Radio) akan menggunakan desain ultra-ramping (ultra-lean design) dengan tujuan untuk memperbaiki skema pensinyalan, baik dalam hal penghematan energi dan untuk memungkinkan pembangunan padat yang dibutuhkan oleh spektrum baru 5G. Awalnya konsep lean design diperkenalkan ke terknologi 4G LTE (Long Term Evolution) untuk meningkatkan kecepatan data dan cakupan aplikasi bagi pengguna, sebagai transisi menuju teknologi 5G.

Prinsip dasar ultra-lean design pada 5G adalah menghilangkan jumlah transmisi data kontrol wideband yang tidak diperlukan (Huawei, 2016). Lean Carrier bekerja dengan mengurangi interferensi 
yang disebabkan oleh sinyal referensi di seluruh jaringan LTE. Hal ini menyebabkan peningkatan kualitas layanan dan kecepatan di sisi user. Dengan mengurangi interferensi, Lean Carrier memungkinkan modulasi orde baru 256 QAM yang lebih tinggi untuk digunakan di area yang lebih luas, sehingga menghasilkan kecepatan data lebih tinggi untuk lingkungan makro luar ruangan (outdoor macro environtment).

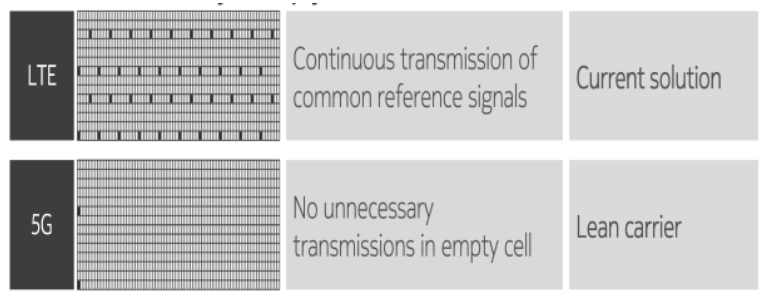

Gambar 5. Aktivitas transmisi sel kosong pada LTE dan 5G (Pederson, 2015)

Penggunaan Lean Carrier pada 5G selain menurunkan interferensi antar sel, juga akan mengurangi jumlah konsumsi daya pada BTS (Base Transceiver Station), serta pada perangkat IoT dan UE (User Equipment). Gambar 5 menunjukkan perbandingan aktivitas transmisi pada sel kosong antara teknologi LTE dan 5G, sedangkan Gambar 6 menunjukkan struktur unified air interface pada 5G.

Unified air interface pada 5G didesain tidak hanya untuk meningkatkan kinerja dan efisiensi mobile broadband saja, namun juga untuk menghubungkan teknologi IoT skala besar serta memungkinkan jenis layanan baru seperti mission critical control yang memerlukan latensi ultra rendah dan level baru di sisi kehandalan (reliability) dan keamanan (security). Desain baru ini akan menyatukan beragam jenis spektrum dan band, skala dari penyebaran makro ke hotspot local, serta secara efisien memultipleks layanan 5G dengan berbagai variasi persyaratan yang ekstrem.

Lapisan L1 dalam susunan protocol unified air interface pada 5G merupakan lapisan fisik abstrak (abstract physical layer). Lapisan ini dirancang untuk mengekstrak titik-titik yang setipe (common points) dari berbagai layanan pada lapisan fisik. Common points belum tentu persis sama, namun bisa dikonfigurasi sama. Oleh karena itu, lapisan L1 transparan ke berbagai layanan dan band frekuensi.

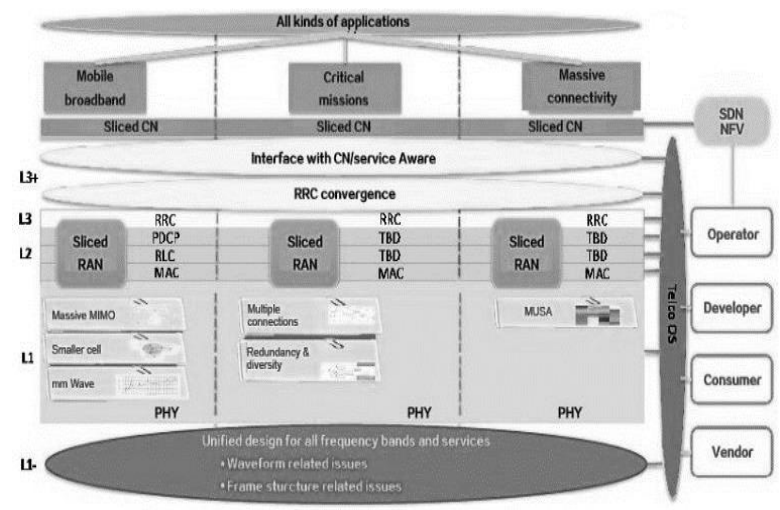

\section{Gambar 6. Struktur unified air interface pada 5G} (Guanghui, 2016)

Dalam sistem 5G, jenis layanan yang berbeda dilakukan pada band frekuensi yang berbeda, sehingga parameter struktur frame harus berbeda. Bukan hal yang baik jika setiap pita frekuensi memiliki parameter frame yang independen. Metode yang efisien dan fleksibel melibatkan scalability. Dengan mengambil parameter struktur frame di LTE sebagai titik awal, didefinisikan faktor scalable $\mathrm{S}$. Semua parameter lainnya, seperti frekuensi sampling, interval sub-carrier, panjang simbol dan panjang $\mathrm{CP}$ (cyclic prefix), dikendalikan oleh parameter $\mathrm{S}$ ini. Selama parameter $\mathrm{S}$ dikonfigurasi dengan benar, layanan dan pita frekuensi yang berbeda dapat didukung oleh struktur frame.

Slice design pada L1, L2 dan L3, layanan yang berbeda memiliki tuntutan yang berbeda, sehingga lapisan ini perlu dirancang sesuai kebutuhan (Guanghui, 2016). Untuk layanan eMBB, L1 berfokus pada massive MIMO, SVC (Scalable Video Coding), dan pelacakan high frequency beam. Selain itu, layanan MBB memiliki sub-layanan yang melimpah, sehingga memerlukan keseluruhan struktur stack L1 / L2 / L3. Dibandingkan dengan eMBB, mMTC memiliki data layanan yang lebih sedikit, sehingga protocol stack L2 / L3-nya tidak sama persis dengan eMBB. Rekonstruksi dan konsolidasi diperlukan untuk mengurangi overhead dari tumpukan protokol. Latency rendah juga diperlukan agar protocol stack bisa disederhanakan sebanyak mungkin. L1, L2 dan L3 memiliki karakteristik yang berbeda. Misalnya, multi-koneksi didefinisikan pada L3; kode koreksi kesalahan (error correction codes) didefinisikan pada L2; dan frequency, time and space diversity digunakan pada L1. 
Lapisan L3+ merupakan lapisan persepsi layanan (service-perception layer). Lapisan ini dirancang untuk membawa bearer dari jaringan inti (core network) ke jaringan akses (access network) dan membedakan berbagai layanan di jaringan akses. Dengan cara ini, setiap layanan dibawa dengan slice yang berbeda dan dikonfigurasi dengan parameter transmisi yang sesuai pada L1.

\section{III.4 Arsitektur Jaringan yang Fleksibel (Versatile Network Architecture)}

Adanya berbagai tuntutan persyaratan yang harus dipenuhi membuat 5G memerlukan pergeseran dari jaringan generasi sebelumnya yang kaku (rigid), menuju jaringan yang lebih fleksibel (versatile) dan mudah beradaptasi (adaptable). Jaringan versatile 5G adalah solusi jaringan lengkap di mana di setiap lapisan jaringan yang berbeda, mulai dari teknologi akses radio hingga ke teknik system-level, dapat beradaptasi dengan cara yang harmonis untuk menyesuaikan kebutuhan layanan tertentu (Dalle, 2017).

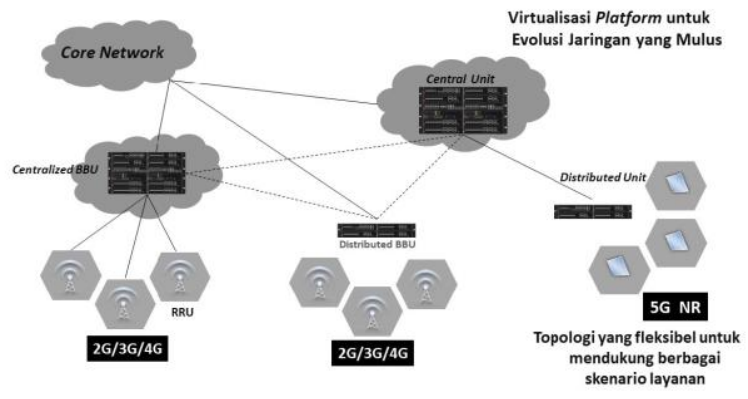

Gambar 7. Arsitektur jaringan 5G yang fleksibel untuk memenuhi semua persyaratan berbagai layanan teknologi

Sejumlah teknologi akses radio terkini yang dipertimbangkan untuk 5G, seperti in-band full duplex (IBFD), new waveforms, mmWave, dan Massive MIMO menunjukkan heterogenitas yang jelas dalam hal kemampuan dan kelebihannya. MmWave, misalnya, menghadirkan tantangan baru karena memiliki sensitivitas ekstrim terhadap penyumbatan (blockage), namun menawarkan pesat data yang luar biasa bila diterapkan di lingkungan yang tepat. Contoh lainnya, penerapan metode IBFD justru memunculkan jenis interferensi yang baru ke dalam jaringan, namun metode ini berpotensi menggandakan efisiensi spektral tergantung pada profil gangguan sel
(Ohlen, 2015). Jadi, teknologi baru itu tidak selalu menawarkan kinerja yang lebih baik dalam setiap situasi, namun lebih bisa memberikan banyak pilihan dan fleksibilitas. Arsitektur jaringan 5G yang fleksibel untuk berbagai jenis layanan ditunjukkan oleh Gambar 7.

\section{KESIMPULAN}

Skenario layanan 5G dapat dibagi menjadi tiga kelompok, yaitu: enhanced Mobile Broadband (eMBB), ultra-Reliable and Low Latency Communications (uRLLC), dan massive Machine Type Communications (mMTC). eMBB menyediakan kapasitas tinggi dan kecepatan tinggi, namun relatif tidak sensitif terhadap jumlah koneksi dan kehandalan. uRLLC terutama dirancang untuk mengurangi latency dan meningkatkan keandalan transmisi data, namun tidak dirancang untuk mengakomodasi sejumlah node atau memberikan pesat transmisi data yang tinggi. mMTC menyediakan akses hemat energi dengan biaya rendah untuk sejumlah node, namun kecepatan transfer data tidak tinggi. Dibandingkan dengan generasi WAN sebelumnya, jaringan akses $5 \mathrm{G}$ harus fleksibel dan terbuka. Ini harus disesuaikan dengan tuntutan individu dan menyediakan antarmuka standar eksternal yang memungkinkan pengguna menyelesaikan tugas spesifik melalui platform akses jaringan 5G. Oleh karena itu, prioritasnya adalah merancang antarmuka udara terpadu (unified air interface) sehingga jaringan akses 5G dapat secara efisien mendukung berbagai jenis layanan yang berbeda. Dengan demikian, empat hal yang menjadi kunci penting implementasi teknologi 5G adalah: teknologi massive MIMO, jaringan hybrid, desain yang ramping dan antarmuka udara terpadu, serta arsitektur jaringan yang fleksibel.

\section{REFERENSI}

Nokia Networks. (2016) 5G Masterplan-Five Keys to Create the New Communications Era, White Paper. [Online]. Tersedia di: http://5g.itrc.ac.ir/sites/default/files/5g_masterplan_whi te_paper.pdf

5G PPP (2016), View on 5G Architecture, 5G PPP Architecture Working Group. [Online]. Tersedia di: https://5g-ppp.eu/wp-content/uploads/2014/02/5GPPP-5G-Architecture-WP-July-2016.pdf

Arjmandi, M. K. (2016). 5G Overview: Key Technologies. [Online].

Tersedia di:
Ulil Surtia Zulpratita

Jurnal Ilmiah Teknologi Informasi Terapan Volume IV, No 2, 30 April 2018 
http://www.ittoday.info/Excerpts/5G-Overview-KeyTechnologies.pdf

Sexton, C., et.al. (2017). 5G: Adaptable Networks Enabled by Versatile Radio Access Technologies. IEEE Communications Surveys \& Tutorials. 19 (2), pp 688$720 . \quad$ [Online]. Tersedia di: http://ieeexplore.ieee.org/document/7815331/

Ohlen, P., et. al. (2015). Flexibility in 5G Transport Networks. Ericsson Technology Review. Vol 92. [Online]. Tersedia di: https://www.ericsson.com/assets/local/publications/eric sson-technology-review/docs/2015/etr-5g-transportnetworks.pdf

Qualcomm Technologies. (2016). Making 5G NR a Reality, Qualcomm. [Online]. Tersedia di: whitepaper-making5g-nr-a-reality.pdf

Dong, Z. (2016). "Up in the Air with 5G", Communicate Issue 80. Huawei. [Online]. Tersedia di: http://wwwfile.huawei.com/ /media/CORPORATE/PDF/publicati ons/communicate/80/15-up-in-the-air-with-5g.pdf

5G PPP. (2015). 5G Vision: The Next Generation of Communication Networks and Services. [Online]. Tersedia di: https://5g-ppp.eu/wpcontent/uploads/2015/02/5G-Vision-Brochure-v1.pdf

Larsson, E.G., et. al. (2014). Massive MIMO for Next Generation Wireless System. [Online]. Tersedia di: https://arxiv.org/pdf/1304.6690.pdf

Cisco. (2017). Cisco Visual Networking Index: Global Mobile Data Traffic Forecast Update, 2016-2021. Whitepaper. [Online]. Tersedia di: http://goo.gl/xxLT

Rappaport, T. S., et.al., (2014). Millimeter wave cellular wireless networks: Potentials and challenges. Proc. IEEE, vol. 102, no. 3, pp. 366-385.

Heath, R.W. (2016). Millimeter Wave for 5G. Finding a New Spectrum Mother Load. The University of Texas, Austin. [Online]. Tersedia di: http://users.ece.utexas.edu/ rheath/presentations/2016/ MillimeterWave5GFindingNewSpectrumMotherLoad. pdf

Rebato, M., et.al. (2017). Hybrid Spectrum Sharing in mmWave Cellular Networks. IEEE Transactions on Cognitive Communications and Networking. 3 (2), pp 155-168. [Online]. Tersedia di: http://ieeexplore.ieee.org/stamp/stamp.jsp?arnumber=7 $\underline{937896}$

Cuba, F. G., et. al., (2014). Scaling Laws For Infrastructure Single and Multihop Wireless Networks In Wideband Regimes. in Proc. IEEE Int. Symp. Inf. Theory (ISIT), Honolulu, HI, USA, pp. 76-80.
Rebato, M., et. al. (2016) Understanding Noise and Interference Regimes in $5 G$ Millimeter-Wave Cellular Networks. in Proc. 22th Eur. Wireless Conf., pp. 1-5.

Ishii, H., et.al., (2012) A Novel Architecture for LTE-B: CPlane/U-Plane Split and Phantom Cell Concept. in Proc. IEEE Globecom Workshops, Anaheim, CA, USA, pp. 624-630.

Andrews, J. G. (2013) Seven Ways That Hetnets are a Cellular Paradigm Shift. IEEE Commun. Mag., vol. 51, no. 3, pp. 136-144.

Ghosh, A., et al. (2014) Millimeter-Wave Enhanced Local Area Systems: A Highdata-Rate Approach for Future Wireless Networks. IEEE J. Sel. Areas Commun., vol. 32, no. 6, pp. 1152-1163.

Elshaer, H., et. al. (2016) Downlink and Uplink Cell Association With Traditional Macrocells and Millimeter Wave Small Cells. IEEE Trans. Wireless Commun., vol. 15, no. 9, pp. 6244-6258

Huawei. (2016). 5G Network Architecture; a High Level Perspective. White Paper. Huawei. [Online]. Tersedia di: http://www.huawei.com/minisite/5g/img/5G_Network _Architecture_A_High-Level_Perspective_en.pdf

Pederson, K. I. (2015). Air Interface Evolution Towards $5 G$. Nokia Networks. IE E E V TC 2015 , Boston, US. [Online]. Tersedia di: http://www.ieeevtc.org/conf-admin/vtc2015fall/14.pdf

Guanghui, Y. (2016). Unified Air Interfaces in $5 G$. ZTE, China. [Online]. Tersedia di: http://wwwen.zte.com.cn/endata/magazine/ztetechnolo gies/2016/no1/articles/201601/t20160115_447458.html

Dalle, G., et.al. (2017). 5G-Convergence. ITU-T Workshops and Seminars. [Online]. Tersedia di: https://www.itu.int/en/ITU-T/Workshops-andSeminars/201707/Documents/Manuel-Paul-5GConvergence.pdf 